\title{
GENETIC VARIATION OF STREPTOMYCIN RESISTANCE IN CLINICAL STRAINS OF STAPHYLOCOCCUS AUREUS
}

\author{
J. GRINSTED AND R. W. LACEY \\ Department of Bacteriology, University of Bristol
}

STRAINS of Escherichia coli can be resistant to high levels of streptomycin (MIC $>1000 \mu \mathrm{g}$ per ml) or only to low levels of the drug (MIC $25 \mu \mathrm{g}$ per ml) (Harwood and Smith, 1969). High-level resistance is usually found in strains that have been exposed to streptomycin in the laboratory; the genes that specify this character are chromosomal and code for altered ribosomes (Weisblum and Davies, 1968). Strains isolated from clinical material usually exhibit low-level resistance; the genes coding for this are carried on $\mathbf{R}$ factors and specify inactivating enzymes (Smith, 1969). Low-level resistance to streptomycin in $E$. coli may be accompanied by resistance to spectinomycin because of the production of a single enzyme that inactivates both drugs (Davies, Brzezinska and Benveniste, 1971).

Some strains of Staphylococcus aureus isolated from clinical material are resistant to high levels of streptomycin, a character determined by chromosomal genes (Lacey, 1972; Lacey and Chopra, 1972); in our experience, lowlevel resistance to the drug also occurs in clinical strains of $S$. aureus. We have examined the frequency of high- and low-level resistance in streptomycinresistant strains of $S$. aureus isolated from clinical material. The coincidence of resistance to streptomycin and to spectinomycin, which can occur in $E$. coli, prompted us to test the streptomycin-resistant strains of $S$. aureus for resistance to other aminoglycosides, particularly spectinomycin. In strains that exhibited low-level resistance to streptomycin, segregation studies suggested that the relevent genes were plasmid-borne; two such strains were examined for plasmid DNA.

\section{MATERIALS AND METHODS}

Organisms. Strains of $S$. aureus were obtained from clinical material between 1967 and 1972 from sources predominantly in Bristol. Each strain was distinct in bacteriophagetyping pattern, antibiotic sensitivity or pigment production. The strains were isolated initially on antibiotic-free medium, then checked by disk-testing for antibiotic sensitivity. Single colonies were used to inoculate nutrient agar slopes, which were then stored at room temperature without subculture.

Media, and methods for the determination of antibiotic sensitivity and delta-haemolysin production, bacteriophage typing, and for attempts at transduction were as described previously (Lacey, 1972).

Treatment with nitrosoguanidine was by the method of Lacey (1971a); the cultures were treated with nitrosoguanidine $(100 \mu \mathrm{g}$ per $\mathrm{ml})$ for sufficient time to give about 10 per cent. survival. 
Isolation of covalently closed circular DNA (CCC-DNA) on ethidium bromide-CsCl gradients, and analysis on sucrose gradients, was as described previously (Lacey and Grinsted, 1972).

Loss of antibiotic resistance was detected by replica plating on media containing the following antibiotics, either singly or in combinations: erythromycin $(10 \mu \mathrm{g}$ per $\mathrm{ml})$, neomycin $(10 \mu \mathrm{g}$ per $\mathrm{ml})$, streptomycin $(10 \mu \mathrm{g}$ per $\mathrm{ml})$, spectinomycin $(500 \mu \mathrm{g}$ per $\mathrm{ml})$, tetracycline $(10 \mu \mathrm{g}$ per $\mathrm{ml})$. Resistance to penicillin (penicillinase) and cadmium ions are linked in strains 100 and 494 ; loss of these was detected by replicating on medium containing cadmium acetate $\left(10^{-4} \mathrm{M}\right)$.

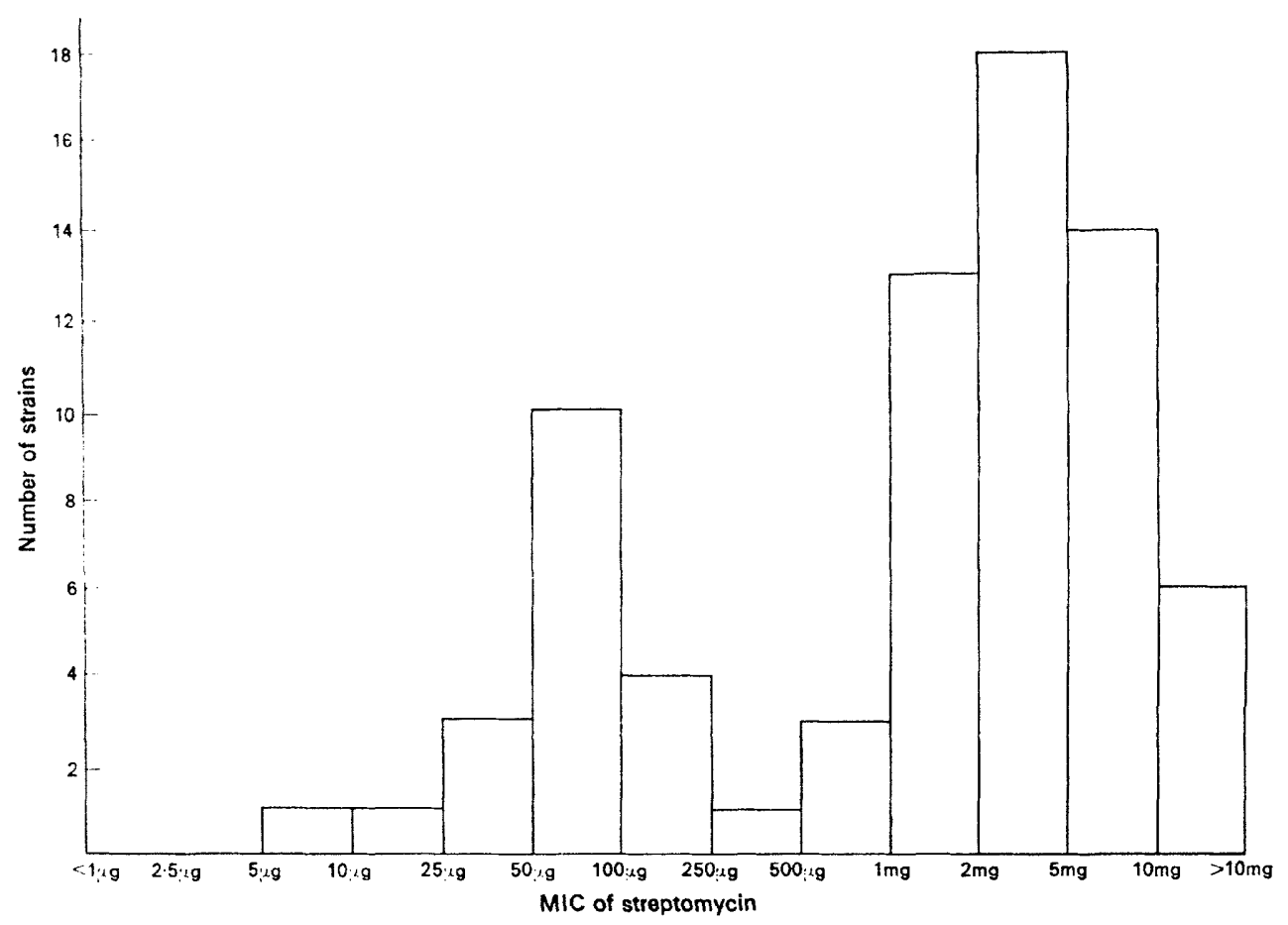

Fig. 1.-Levels of resistance in 74 distinct streptomycin-resistant strains of Staphylococcus aureus.

\section{RESULTS}

Level of streptomycin-resistance in clinical strains of $S$. aureus

Strains of $S$. aureus isolated from clinical specimens were initially classed as sensitive or resistant on the basis of disk testing. Of 30 " sensitive" strains, all were inhibited by $1 \mu \mathrm{g}$ per $\mathrm{ml}$ of streptomycin; for 74 " resistant" strains, the MIC of streptomycin varied from $10 \mu \mathrm{g}$ per $\mathrm{ml}$ to $>5 \mathrm{mg}$ per $\mathrm{ml}$ (fig. 1). Of these resistant strains, 51 (69 per cent.) showed high-level resistance (defined as MIC of at least $1 \mathrm{mg}$ per $\mathrm{ml}$ ) and 19 (26 per cent.) showed low-level resistance (MIC of 10 to $250 \mu \mathrm{g}$ per $\mathrm{ml}$ ); a few (four) were resistant to intermediate levels of the drug. Four strains with low-level resistance (strains 100, 494, 649 and FAR4) and four with high-level resistance (strains 186, 342, 642 and 805) were examined further. 


\section{Stability of streptomycin resistance}

Bacteria from the original nutrient-agar slopes (inoculated at the times of isolation shown in table I) were grown overnight in nutrient broth and then examined for loss of resistance by replica plating. None of about 4000 colonies of each of the four high-level-resistant strains were now sensitive to the drug (table I). But many colonies of the low-level-resistant strains 100, 494 and 649 were now sensitive to streptomycin (table I). Strain 649 is resistant only to streptomycin; but strains 100 and 494 are multi-resistant (table I), and during

TABLE I

Properties of some streptomycin-resistant strains of Staphylococcus aureus

\begin{tabular}{|c|c|c|c|c|c|c|}
\hline \multirow[b]{2}{*}{$\begin{array}{l}\text { Index } \\
\text { number } \\
\text { of strain }\end{array}$} & \multirow[b]{2}{*}{$\begin{array}{l}\text { Year of } \\
\text { initial } \\
\text { isolation }\end{array}$} & \multirow[b]{2}{*}{$\begin{array}{l}\text { MIC of } \\
\text { strepto- } \\
\text { mycin } \\
\text { (per ml) }\end{array}$} & \multirow[b]{2}{*}{$\begin{array}{c}\text { Resistance } \\
\text { to other } \\
\text { anti- } \\
\text { biotics }\end{array}$} & \multirow[b]{2}{*}{ Phage-typing pattern } & \multicolumn{2}{|c|}{$\begin{array}{c}\text { Loss of streptomycin resistance } \\
\text { on storage* }\end{array}$} \\
\hline & & & & & $\begin{array}{l}\text { number of } \\
\text { colonies examined }\end{array}$ & $\begin{array}{l}\text { number } \\
\text { of colonies } \\
\text { sensitive to } \\
\text { streptomycin } \\
\text { (per cent.) }\end{array}$ \\
\hline $\begin{array}{l}186 \\
342 \\
642 \\
805 \\
100 \\
494 \\
649\end{array}$ & $\begin{array}{l}1967 \\
1968 \\
1968 \\
1969 \\
1967 \\
1968 \\
1968\end{array}$ & $\begin{array}{r}5 \mathrm{mg} \\
2 \mathrm{mg} \\
10 \mathrm{mg} \\
10 \mathrm{mg} \\
100 \mu \mathrm{g} \\
100 \mu \mathrm{g} \\
100 \mu \mathrm{g}\end{array}$ & $\begin{array}{l}\text { PTE } \\
\text { PT } \\
\text { PTE } \\
\text { PTEN } \\
\text { PTEN } \\
\text { PTEN }\end{array}$ & $\begin{array}{l}77 \\
80 \\
6 / 42 \mathrm{E} / 47 / 53 / 54 / 75 / 85 \\
47 / 53 / 54 / 77 / 84 / 85 / 88 \\
75 / 77 / 83 \mathrm{~A} / 84 / 85 \\
6 / 42 \mathrm{E} / 47 / 53 / 54 / 75 / 85 / 88 / 81\end{array}$ & $\begin{array}{r}4200 \\
3800 \\
3800 \\
4400 \\
300 \\
320 \\
63\end{array}$ & $\begin{array}{l}0 \\
0 \\
0 \\
0 \\
124(41) \dagger \\
61(20) \dagger \\
50(80)\end{array}$ \\
\hline FAR4 & 1971 & $100 \mu \mathrm{g}$ & PFEN & $\mathbf{3 A}$ & \multicolumn{2}{|c|}{ See Lacey et al. (1973) } \\
\hline
\end{tabular}

$\mathbf{P}=$ Resistant to penicillin (penicillinase producer); $\mathbf{F}=$ to fusidic acid; $T=$ to tetracycline; $\mathrm{E}=$ to erythromycin; $\mathrm{N}=$ to neomycin.

* Duration of storage was from their date of initial isolation to 1972.

$\uparrow$ Data extracted from table II.

identification of colonies derived from these two strains, a variety of sensitivity patterns was noted (table II). In particular, it can be seen that loss of streptomycin resistance was always accompanied by loss of resistance to neomycin. The phage-typing pattern of one colony of each sensitivity type was determined: it resembled that of the corresponding wild strain in every case. No streptomycin-sensitive derivatives of the low-level-resistant strain FAR4 (isolated in 1971) have been found after storage for $6 \mathrm{mth}$. However, treatment of strain FAR4 with cloxacillin resulted in the appearance of sensitive derivatives (Lacey, Lewis and Grinsted, 1973).

The stability of streptomycin resistance in the high-level-resistant strains is consistent with a chromosomal location for the genes coding for this resistance; the instability of the low-level resistance in strains 100, 494, 649 and FAR4 suggests that the relevant genes in this case are plasmid-borne. The instability of the other resistances in strains 100, 494 (see above) and FAR4 (Lacey et al.) suggests that these also are determined by plasmid-borne genes. Other 
resistances in the high-level-resistant strains were not tested for instability. But streptomycin resistance could not be transduced from strains 100, 494 or 649 , either by the use of mitomycin C-induced lysates or by propagation of typing phages 88,85 and $83 \mathrm{~A}$. This was not due to some peculiarity of these strains, because tetracycline resistance could be transduced from strains 100 and 494, and a derivative of strain 649 harbouring a plasmid determining tetracycline resistance could also transduce this resistance. Attempts at transduction with strain FAR4 were unsuccessful (Lacey et al.).

\section{Effects of nitrosoguanidine on strains 100, 494 and FAR4}

Strains 100 and 494 were treated with nitrosoguanidine and about 8000 colonies of each then tested for resistance to streptomycin and neomycin.

TABLe II

Antibiotic resistance of strains 100 and 494 after storage*

Resistant to $\dagger \overbrace{\text { strain } 100 \quad \text { strain } 494}^{\text {Number of colonies of }}$

\begin{tabular}{crr}
\hline PTSNE & 2 & 7 \\
TSNE & 166 & 246 \\
T E & 116 & 58 \\
PT E & 8 & 3 \\
TSN & 5 & 3 \\
SNE & 3 & 3
\end{tabular}

* Both strains were originally resistant to PTSNE; strain 100 was stored for $5 \mathrm{yr}$ and strain 494 for 4 yr.

$\dagger \mathbf{S}=$ Streptomycin; other abbreviations as table $\mathbf{I}$.

Three of the colonies of strain 100 were sensitive to neomycin but resistant to streptomycin, and two were resistant to neomycin but sensitive to streptomycin. Similarly, in strain 494 , loss of neomycin resistance without loss of streptomycin resistance occurred in one colony and vice versa in four. Thus, the genes specifying resistance to streptomycin and to neomycin in strains 100 and 494 are probably distinct.

Strain FAR4 is resistant to penicillin, fusidic acid, neomycin, streptomycin, and erythromycin and produces $\delta$-haemolysin. These characters may be lost after exposure of the strain to cloxacillin, and the patterns of these characters observed in colonies after treatment with cloxacillin suggested that there is an association between the capacity to produce $\delta$-haemolysin and resistance to streptomycin, neomycin and erythromycin (Lacey et al.). This possibility has been investigated by observing the frequencies of the various patterns of characters after treatment of the strain with nitrosoguanidine. All four characters could be lost singly, $\delta$-haemolysin production being lost at a greater frequency than the others (table III). But loss of resistance to neomycin was often associated with loss of streptomycin resistance, and sometimes with loss 
of $\delta$-haemolysin production; and occasionally loss of erythromycin resistance was associated with loss of resistance to both streptomycin and neomycin (table III). No colonies were found that had lost erythromycin resistance, streptomycin resistance and $\delta$-haemolysin production while retaining neomycin resistance; similarly, no colonies were found that retained only streptomycin resistance. Genes with high co-mutation frequencies following treatment with nitrosoguanidine are closely linked (Guerola, Ingraham and Cerdá-Olmedo, 1971). If this conclusion is applied to the characters studied here, they are linked in the following order: erythromycin resistance-streptomycin resistanceneomycin resistance- $\delta$-haemolysin production. This sequence is also consistent with the patterns resulting from loss in vivo and after exposure to cloxacillin in vitro (Lacey et al.).

TABLE III

Loss of antibiotic resistance and $\delta$-haemolysin production from 16,500 colonies of strain FAR4 after treatment with nitrosoguanidine

\begin{tabular}{ccc} 
Resistant to* & $\delta$-Haemolysin & $\begin{array}{c}\text { Number of } \\
\text { colonies }\end{array}$ \\
\hline ESN & - & 238 \\
ES & + & 8 \\
E N & + & 26 \\
SN & + & 15 \\
E & + & 28 \\
ES & - & 12 \\
None & + & 4
\end{tabular}

$+=$ Detected; $-=$ not detected.

* Abbreviations as table II. Resistance to penicillin and to fusidic acid was not examined.

\section{Analysis of plasmid DNA from strains 649 and FAR4}

Plasmid DNA in S. aureus can be isolated as CCC-DNA; and this can be separated from other forms of DNA by ethidium bromide/CsCl-gradient centrifugation (see, for example, Lacey and Grinsted). In ethidium bromide/ CsCl-gradients, DNA from strain 649 (streptomycin resistant) formed two bands, a major band of chromosomal DNA and a satellite band of CCC-DNA on the dense side of this major band; DNA from a streptomycin-sensitive derivative of strain 649 , on the other hand, formed only a single band of chromosomal DNA (fig. 2). It is inferred that the CCC-DNA in strain 649 is a plasmid that carries the genes coding for resistance to streptomycin. This plasmid DNA sedimented as two bands in sucrose gradients (fig. 3); on storage of the preparation, the slower-sedimenting band increased at the expense of the fastersedimenting (data now shown), indicating that these two bands represent respectively the CCC form and the open circular form of the same species of plasmid DNA. By reference to an internal sedimentation marker of RP1-DNA (whose open circular form sediments at 43S, see Grinsted et al., 1972), the S-value of the open circular form of the plasmid DNA from strain 649 was 
estimated as about $42 \mathrm{~S}$ (fig. 3). This corresponds to a molecular weight of about 38 million daltons (Studier, 1965; Vinograd et al., 1965).

The other low-level-resistant strains 100, 494 and FAR4 differ from strain 649 , by being multi-resistant (see table I). This suggests that there is more than one plasmid in these strains, and this might cause difficulties in the analysis of plasmid DNA. Strain FAR4 was selected as an example of these multi-resistant strains and attempts have been made to analyse its plasmid DNA.

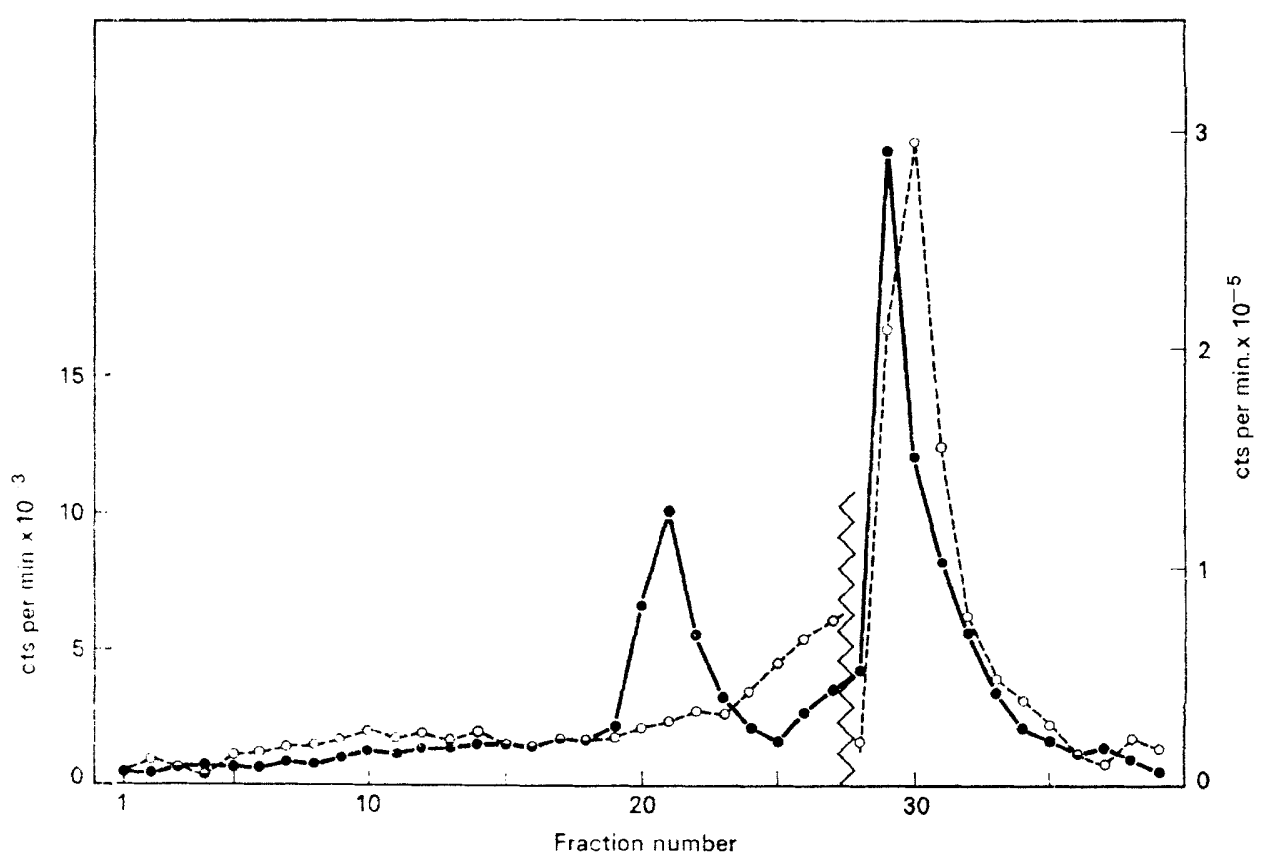

FIG. 2.-Ethidium bromide/CsCl-gradient analysis of strain 649.

Cultures were labelled with ${ }^{3} \mathrm{H}$-thymidine, lysed and then analysed on ethidium bromide/ CsCl-gradients as described by Lacey and Grinsted (1972). - strain 649 (streptomycin resistant); $0--0$, a streptomycin-sensitive derivative of strain 649. (Note the change of scale between fractions 27 and 28.)

Strain FAR4 and all partially resistant derivatives that have been tested contained CCC-DNA (data now shown); we have been unable to obtain a derivative that does not contain CCC-DNA. The CCC-DNA of strain FAR4 was analysed on sucrose gradients and fig. 4 shows examples of the profiles that resulted. It can be seen that it appeared as a slow-sedimenting, well-defined band and a faster-sedimenting, but very ill-defined band (fig. 4, trace 1). This might indicate that this CCC-DNA consisted of a small plasmid (the slowsedimenting band), and a number of larger plasmids sedimenting at about the same rate. However, it is apparent from the profiles of CCC-DNA from partially resistant derivatives shown in fig. 4 that there was no obvious correlation between the species of CCC-DNA and the phenotypic characters of the derivatives. So it appears that the status of plasmid DNA in this multiresistant strain is too complicated for analysis by this technique. Indeed, 
there is no evidence here to suggest that the CCC-DNA in these strains is necessarily related to their antibiotic resistance.

\section{Spectinomycin resistance in $S$. aureus}

The 74 streptomycin-resistant and 30 other multi-resistant strains were tested for resistance to spectinomycin. Strains were inhibited by either 25 to $100 \mu \mathrm{g}$ of spectinomycin per $\mathrm{ml}$ (defined as sensitive) or by $>1000 \mu \mathrm{g}$ per ml

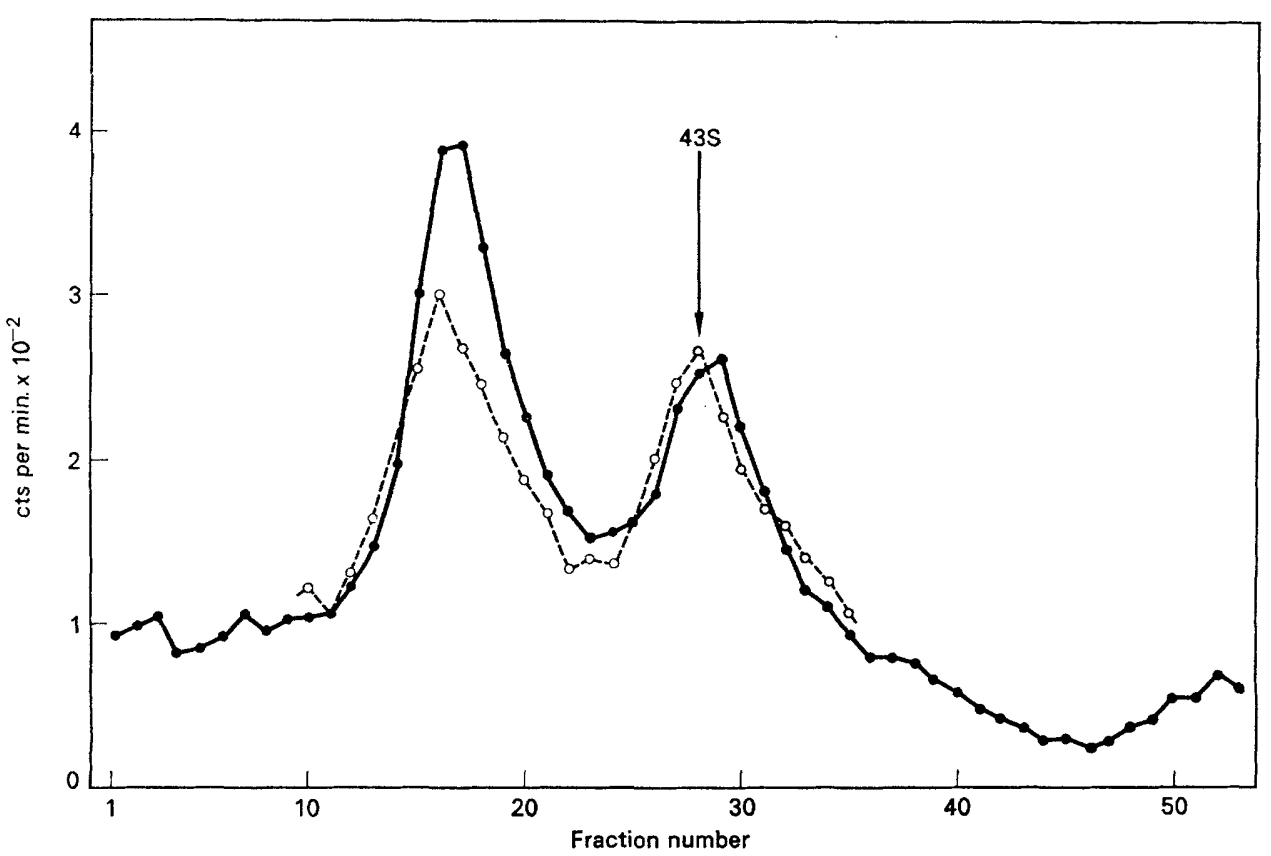

Fig. 3.-Sucrose-gradient analysis of CCC-DNA from strain 649.

Tritium-labelled CCC-DNA, isolated from strain 649 as shown in fig. 2, was mixed with 14C-labelled RP1-DNA (Grinsted et al., 1972); the mixture was then analysed on neutral sucrose gradients as described by Grinsted et al. Centrifugation was for $90 \mathrm{~min}$. $-0,{ }^{3} \mathrm{H}$ (CCC- DNA from strain 649); $0--0,14$ C(RP1-DNA).

(resistant), but there was no association of streptomycin resistance and spectinomycin resistance. However, all strains that were resistant to spectinomycin were also resistant to erythromycin. Furthermore, derivatives of strains 100 and 494 that had lost erythromycin resistance on storage (see table II) had also lost spectinomycin resistance.

An association of erythromycin resistance and spectinomycin resistance is further indicated by co-transduction. Strains 2273 and 11164 contain plasmidborne erythromycin resistance (Lacey, 1972). Erythromycin resistance was transduced from these strains by means of mitomycin C-induced lysates: all of 2500 transductants examined were resistant to both erythromycin and spectinomycin. Thus, it is probable that the genes determining these two resistances in these strains are either very closely linked or identical. 


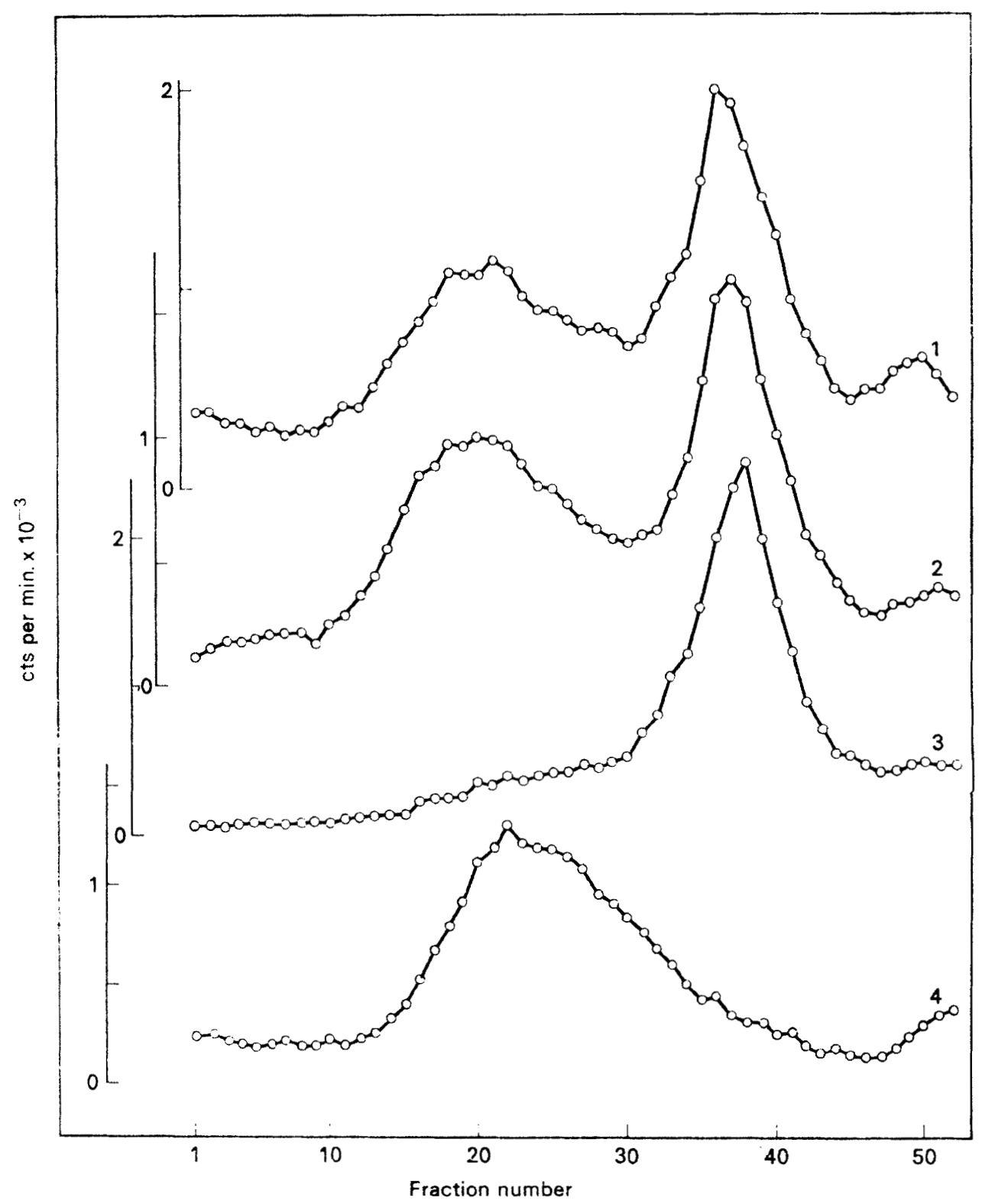

Fig. 4.-Sucrose-gradient analysis of CCC-DNA from strain FAR4.

Radioactive CCC-DNA was isolated from strain FAR4 and its derivatives on ethidium bromide/CsCl-gradients and then analysed on neutral sucrose gradients. Centrifugation was for $120 \mathrm{~min}$.

Traces shown describe CCC-DNA from derivatives with the following phenotypes $(\delta \mathrm{H}=$ production of $\delta$-haemolysin; other abbreviations indicate the resistances described in table I): trace 1, PFSNE $\delta \mathrm{H}$ (wild strain); trace 2 , SNE $\delta \mathrm{H}$; trace $3, \mathrm{PFSNE}$; trace 4 , SNE.

Strain FAR4 is resistant to a number of drugs including erythromycin, streptomycin and neomycin (see table $\mathrm{I}$ ); it is also resistant to spectinomycin. 
But spectinomycin resistance is not linked to erythromycin resistance in this strain; derivatives resistant to erythromycin and sensitive to streptomycin and neomycin were inhibited by $200 \mu \mathrm{g}$ of spectinomycin per $\mathrm{ml}$, and those sensitive to all three drugs were inhibited by $50 \mu \mathrm{g}$ per $\mathrm{ml}$. However, derivatives sensitive to erythromycin and resistant to streptomycin and neomycin (also resistant to kanamycin and paromomycin) were not inhibited by $2000 \mu \mathrm{g}$ of spectinomycin per $\mathrm{ml}$. The latter were treated with nitrosoguanidine and 14 colonies were obtained that were resistant to streptomycin and sensitive to neomycin; all of these colonies were also sensitive to spectinomycin (MIC of $50 \mu \mathrm{g}$ per ml), kanamycin, and paromomycin. Thus, in strain FAR4, spectinomycin resistance is associated with neomycin, kanamycin, and paromomycin resistance. Neomycin-kanamycin-paromomycin resistance is not associated with resistance to spectinomycin in other strains of $S$. aureus, e.g., no. 609 (Lacey, 1971b).

\section{Discussion}

Soon after the introduction of streptomycin to clinical use there were reports of resistant strains appearing during treatment (e.g., Garrod, 1950). Streptomycin resistance is easily obtained in vitro and is due to altered ribosomes (Weisblum and Davies, 1968), and it was considered likely that the same event was occurring in vivo. But the identification of $\mathrm{R}$ factors specifying inactivating enzymes as the cause of resistance in clinical isolates of $E$. coli (Smith, 1969; Davies et al., 1971) showed that the nature of resistance in clinical strains of $E$. coli was different from that in laboratory mutants.

Most acquired antibiotic resistance in $S$. aureus is thought to be determined by plasmid-borne genes (Novick and Bouanchaud, 1971), and it appears reasonable to assume that streptomycin resistance is also determined by such genes. Indeed, Ayliffe (1970) and Grubb and O'Reilly (1971) provide evidence for this in a few strains. But high-level resistance to streptomycin, determined by chromosomal genes, which probably code for altered ribosomes, has been described in clinical strains of $S$. aureus (Lacey, 1972; Lacey and Chopra, 1972). It has been shown in this paper that about 70 per cent. of 74 streptomycinresistant strains of $S$. aureus isolated from clinical sources were resistant to high levels of the drug. The resistance in four of these strains was stable on prolonged storage, and it is probable that the genes determining high-level resistance are chromosomal and presumably code for altered ribosomes.

However, about 30 per cent. of the streptomycin-resistant strains exhibited low-level resistance. In the four of these that were tested, the resistance was unstable, suggesting a plasmid locus for the requisite genes. In one of these (strain 649) there was a correlation between the presence of plasmid DNA and resistance to streptomycin, and it was inferred that this plasmid carried the genes coding for streptomycin resistance. The molecular weight of this plasmid is about 38 million daltons, which is at least twice that of any other staphylococcal plasmid characterised (Novick and Bouanchaud; Lacey and Grinsted, 1972). The size of the plasmid that determines streptomycin resistance may explain why transduction of this resistance could not be detected. 
Strain FAR4 is another strain exhibiting low-level resistance to streptomycin. Evidence is presented suggesting that streptomycin resistance in this strain is linked to neomycin resistance, erythromycin resistance and production of $\delta$-haemolysin. But the nature of this postulated linkage is unclear: it must be easily broken, because some of these characters were lost individually on treatment of the strain with cloxacillin. The instability of the antibiotic resistances suggested that they were determined by plasmid-borne genes, and strain FAR4 does contain CCC-DNA. But there was no correlation between the species of CCC-DNA present and the phenotype; and we cannot even be certain that the CCC-DNA is anything to do with the antibiotic resistances. It is conceivable that the genes determining antibiotic resistances in this strain are on an extra-chromosomal element that is not in a CCC form, as may be the case for genes determining production of pigment and survival (Grinsted and Lacey, 1973).

Low-level resistance to streptomycin can be related to spectinomycin resistance in E. coli (Davies et al.); this is not the case in S. aureus. Apart from one strain (FAR4), in which spectinomycin resistance was associated with neomycin resistance, resistance to spectinomycin in $S$. aureus has been shown to be associated with erythromycin resistance. The molecular basis for such an association is difficult to envisage.

\section{SUMMARY}

Of 74 distinct strains of Staphylococcus aureus obtained from clinical sources, about 70 per cent. were resistant to high levels of streptomycin (MIC $>1 \mathrm{mg}$ per $\mathrm{ml}$ ) and 30 per cent. resistant to lower levels (MIC about $100 \mu \mathrm{g}$ per ml).

Streptomycin resistance in four strains exhibiting high-level resistance was stable on storage, whilst that in four strains with low-level resistance was unstable. Three of the latter were also resistant to other antibiotics; these resistances were also unstable, and in one of these strains (FAR4) there was evidence that streptomycin resistance was linked to erythromycin and neomycin resistance and to production of $\delta$-haemolysin.

Strain 649 is resistant only to streptomycin (low-level resistance); plasmid DNA with a molecular weight of about 38 million daltons corresponding to this resistance was isolated from this strain. Attempts to correlate the CCCDNA from the multi-resistant strain FAR4 with its resistances were unsuccessful.

Resistance to spectinomycin was not associated with resistance to streptomycin, but with erythromycin resistance or with neomycin resistance.

We thank Dr V. G. Alder for bacteriophage-typing facilities. This work was partially supported by a grant from the Medical Research Council to Professor M. H. Richmond.

\section{REFERENCES}

AylifFe, G. A. J. 1970. Stability of neomycin resistance in Staphylococcus aureus. J. Clin. Path., 23, 19.

Davies, J., Brzezinska, M., AND Benveniste, R. 1971. R Factors: biochemical mechanisms of resistance to aminoglycoside antibiotics. Ann. N.Y. Acad. Sci., 182, 226. 
Garrod, L. P. 1950. Acquired bacterial resistance to chemotherapeutic agents. Bull. Hyg., $25,539$.

GRINSTED, J., AND LACEY, R. W. 1973. Ecological and genetic implications of pigmentation in Staphylococcus aureus. J. Gen. Microbiol., 75, 259.

Grinsted, J., Saunders, J. R., Ingram, L. C., Sykes, R. B., and Richmond, M. H. 1972. Properties of an R-factor which originated in Pseudomonas aeruginosa 1822. J. Bact., 110, 529.

GRUBB, W. B., AND O'ReILLY, R. J. 1971. Joint transduction of separate extrachromosomal drug resistance determinants in Staphylococcus aureus E169. Biochem. Biophys. Res. Commun., 42, 377.

Guerola, N., Ingraham, J. L., AND Cerdá-Olmedo, E. 1971. Induction of closely linked multiple mutations by nitrosoguanidine. Nature New Biol., 230, 122.

HaRwOOD, J. H., AND SMITH, D. H. 1969. Resistance factor-mediated streptomycin resistance. J. Bact., 97, 1262.

LACEY, R. W. 1971a. Transfer of tetracycline-resistance between strains of Staphylococcus aureus in mixed cultures. J. Gen. Microbiol., 69, 229.

LACEY, R. W. 1971b. High-frequency transfer of neomycin resistance between naturallyoccurring strains of Staphylococcus aureus. J. Med. Microbiol., 4, 73.

LACEY, R. W. 1972. Genetic control in methicillin-resistant strains of Staphylococcus aureus. J. Med. Microbiol., 5, 497.

LACEY, R. W., AND CHOPRA, I. 1972. Evidence for mutation to streptomycin resistance in clinical strains of Staphylococcus aureus. J. Gen. Microbiol., 73, 175-180.

LACEY, R. W., AND GRINSTED, J. 1972. Linkage of fusidic acid resistance to the penicillinase plasmid in Staphylococcus aureus. J. Gen. Microbiol., 72, 501.

LACEY, R. W., LeWIS, E., AND GRINSTED, J. 1973. Loss of antibiotic resistance in Staphylococcus aureus in vivo probably resulting from cloxacillin therapy. J. Med. Microbiol., 6, 191.

Novick, R. P., AND Bouanchaud, D. 1971. Extrachromosomal nature of drug resistance in Staphylococcus aureus. Ann. N.Y. Acad. Sci., 182, 279.

SMITH, D. H. 1969. R-factors for aminoglycoside antibiotics. J. infect. Dis., 119, 378.

STUDIER, F. W. 1965. Sedimentation studies of the size and shape of DNA. J. Molec. Biol., $11,373$.

Vinograd, J., Lebowitz, J., Radloff, R., Watson, R., ANd Laipis, P. 1965. The twisted circular form of polyoma viral DNA. Proc. Natn Acad. Sci., U.S.A., 53, 1104.

Weisblum, B., AND Davies, J. 1968. Antibiotic inhibitors of the bacterial ribosome. Bact. Rev., 32, 493. 